\title{
Improving Public Services: \\ Public Administration Reform in Northern Ireland
}

Colin Knox \& Paul Carmichael ${ }^{1}$

Journal of Social Policy Volume 35 (1): 97-120

Contact details:

School of Policy Studies

University of Ulster

Shore Road

Jordanstown

Northern Ireland

BT 37 OQB

Telephone: 02890366667 or 90368896

Fax: 02890366847

Email: cg.knox@ulster.ac.uk

p.carmichael@ulster.ac.uk

$25^{\text {th }}$ October 2004

Word count: 7856

\footnotetext{
${ }^{1}$ The authors wish to acknowledge the support for the research in this paper from the ESRC Devolution and Constitutional Change Programme. We would also like to thank anonymous referees for helpful comments on the paper.
} 


\title{
Improving Public Services: Public Administration Reform in Northern Ireland
}

\begin{abstract}
The devolved government in Northern Ireland set about the task of putting in place ' $a$ modern and effective system of public administration that can deliver high quality public services to our citizens'. It did so through a review of public administration launched in June 2002. This paper offers a formative evaluation of the quest to improve the quality of public services, now being taken forward by a British minister since the suspension of devolution. It argues that the review is being driven by institutional concerns and is devoid of a public service modernising agenda. Additionally, it contends that how people in Northern Ireland perceive public services is contingent on their views on its constitutional status (Direct Rule or devolved government) which, in turn, is linked to their support for the Belfast (Good Friday) Agreement, rather than the performance of public bodies. As a consequence, the reforms may result in little more than institutional tinkering with doubtful impact on the quality of public services.
\end{abstract}

\section{Introduction}

The current structure of public administration in Northern Ireland has evolved in a piecemeal fashion as a response to the wider political developments in the Province since the prorogation of its Parliament (Stormont) in March 1972. That the system of public administration should reflect the socio-economic and political milieu, in itself, is no surprise. What is different about Northern Ireland is that the abuse of power in the execution of public services played a significant part in the demise of devolution from 1921-72 and paved the way for a system of public administration so distinctive from other parts of the United Kingdom as to earn it the rather dubious title of 'a place apart' (Rose, 1971). With the collapse of the Northern Ireland Parliament and the subsequent imposition of Direct Rule from Westminster, a system of public administration evolved as a short-term expedient until such times as 'solutions' to macro constitutional issues could be found. In the absence of a political settlement, temporary administrative arrangements bedded in, described by Bloomfield (1998) (former head of the Northern Ireland Civil Service) as a state of 'permanent impermanence'. Reflecting on the period since 1972 one politician argued 'the quality of government services in Northern Ireland too often lets down the people who are using them and who are paying for them through their taxes. That is in part, although 
not entirely, a legacy of nearly four decades of violence' (Lidington, 2004). With a major political development to restore a devolved administration in the form of the Belfast (Good Friday) Agreement, participating parties agreed that it was time to take stock of the way in which public services are delivered in Northern Ireland through a Review of Public Administration. In light of the Review this paper will attempt to do 3 key things. First, it will describe the complex edifice that is the Northern Ireland public sector which has led to charges that it is both over-governed and overadministered (Carmichael \& Osborne, 2003; Knox, 1999). Second, it will contextualise and explicate the current reform process and emerging changes proposed for the public sector. Third, using attitudinal survey data, it will evaluate empirically these proposals against the Minister's assertion that 'improving services lies at the heart of any new model of public administration for Northern Ireland'.

\section{The current system of public administration}

The current system of public administration in Northern Ireland dates back only to December 1999 at which point power was devolved to the Northern Ireland Assembly and its Executive Committee as a result of the 1998 Belfast (Good Friday) Agreement $^{2}$. Devolution in Northern Ireland is part of the wider constitutional reform agenda of the Labour Government which has seen powers devolved to the Scottish Parliament, Welsh Assembly, London Assembly and the future possibility of English regional assemblies. Devolution itself is seen by the government as integral to a wider modernising approach of renewal and reform of public services, the aims of which are: to ensure that policy making is more joined up and strategic; public service users, not providers, are the focus of activities; and public services are high quality and efficient (Cabinet Office, 1999). Devolved government in Northern Ireland witnessed the six pre-existing government departments responsible for public services under Direct Rule reconfigured and expanded to ten departments with an additional department (Office of the First Minister and Deputy First Minister - OFMDFM) to manage the Programme for Government and the agenda of the new Executive. The restructuring of departments had no administrative logic but was the outcome of political negotiations between the main political parties (but mostly the Ulster Unionists and the SDLP) who agreed that the Northern Ireland Executive should

\footnotetext{
${ }^{2}$ Devolved government in Northern Ireland is currently suspended (at the time of writing, October 2004) since October 2002. There have been four periods of devolution since the Belfast (Good Friday) Agreement: $2^{\text {nd }}$ December $1999-11^{\text {th }}$ February 2000; 30 ${ }^{\text {th }}$ May $2000-10^{\text {th }}$ August $2001 ; 12^{\text {th }}$ August $2001-21^{\text {st }}$ September 2001; and, $23^{\text {rd }}$ September $2001-14^{\text {th }}$ October 2002.
} 
comprise 12 ministers - six unionists and six nationalists ${ }^{3}$. As Wilson (2001: 74) reported, 'the unspoken calculus was that Sinn Féin would not be satisfied with only one executive seat; ten departments were required to ensure the party enjoyed two. The result was an allocation of ministerial positions as follows: Sinn Féin two, SDLP three, Ulster Unionist Party three and Democractic Unionist Party two'. Additionally, the Office of the First Minister and Deputy First Minister has two junior ministers. These political machinations therefore dictated the current structure of government with each department headed by a minister (and OFMDFM two junior ministers). Politically-derived administrative changes were not however a completely new experience for Northern Ireland. As a former Head of the Civil Service recounts 'in 1973-74 when departmental structures were last re-examined in the context of impending devolution, a major influence was the imperative to find ministerial posts capable of accommodating a specific political balance in a coalition context' (Bloomfield, 1998: 146).

The eleven government departments are responsible for the bulk of 'transferred' public services ${ }^{4}$ and, under devolved government arrangements, are accountable to ministers who liaise with their respective statutory committees (for each of the 10 departments). The committees are there 'to advise and assist each Northern Ireland Minister in the formulation of policy with respect to matters within his/her responsibilities as a Minister' (Northern Ireland Act, 1998: section 29). In 2003-4 the total expenditure on devolved public services in Northern Ireland is $£ 7.32$ billion (see figure 1) with a staffing complement of 29,500 civil servants ${ }^{5}$ (OFMDFM, 2004). 'Next Steps' executive agencies have been established in several of the departments to deliver services within a policy and resources framework which sets out policy objectives, budgets, specific targets and results to be achieved. Agencies were a direct 'readacross' from policy developments following the Ibbs Report in Great Britain (Efficiency Unit, 1988) which recommended that the work of each government

\footnotetext{
${ }^{3}$ The Northern Ireland Act 1998: Section 17 states that the First and Deputy First Minister acting jointly may determine the number of ministerial offices to be held by Northern Ireland ministers, and the functions of each. There must be one such minister for each Northern Ireland department. The Assembly, with cross-community support, must approve the determination.

${ }^{4}$ The Secretary of State for Northern Ireland remains responsible for 'excepted' and 'reserved' matters. Excepted matters are those matters of concern to the United Kingdom as a whole where no local variation is possible, such as defence, foreign policy and taxation. Reserved matters are powers that have not been transferred to the devolved Assembly but which could be at a later stage, such as policing and criminal justice.

${ }^{5}$ Staffing figures are taken from Equal Opportunities in Northern Civil Service Report (Department of Finance and Personnel, May 2003). The figures do not include direct recruits to the Northern Ireland Assembly, Police Sevice of Northern Ireland and the Northern Ireland Prison Service.
} 
department must be organised in a way which focussed on the job to be done - the systems and structures must enhance the effective delivery of policies and services. There are 18 executive agencies ${ }^{6}$ ranging from the Water Service which has a budget of almost $£ 250 \mathrm{~m}$ and over 2,000 staff, to the Public Records Office with a $£ 2.3 \mathrm{~m}$ budget and around 70 staff. Overall some $48 \%$ of civil servants work within executive agencies of devolved departments (OFMDFM, 2003a).

\section{Figure 1: Public Expenditure 2003-04}

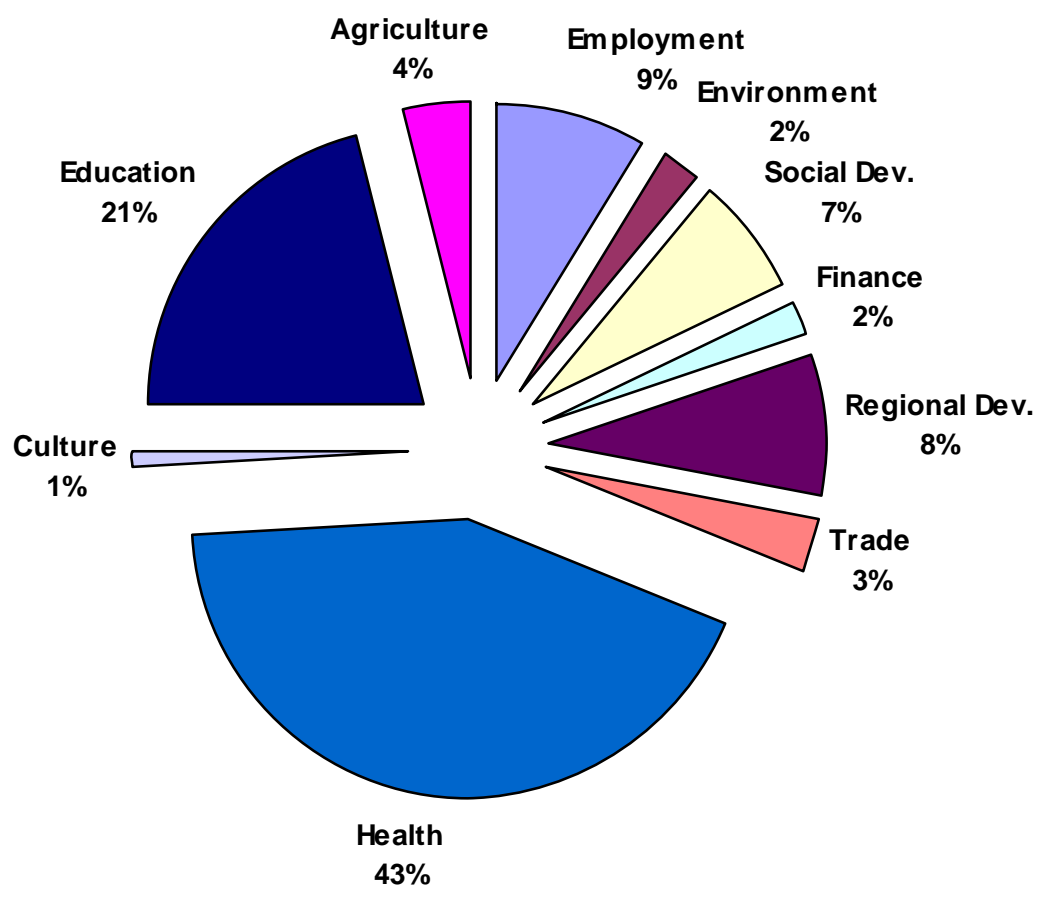

Whilst this accounts for those services currently operated by civil service departments, the overall administrative edifice for a population of 1.7 million people is much more complex. The Northern Ireland public sector is a mosaic of departments, agencies, non-departmental public bodies and local government (see figure 2). Non-departmental public bodies or quasi-autonomous non-governmental organisations (quangos) perform key executive and advisory roles in public services in Northern Ireland. Quangos are set up to carry out functions that are best delivered at arm's length from government. In the case of Northern Ireland however, a number of functions ordinarily within the remit of local government in other parts of the United Kingdom, were assigned to quangos (following the Macrory Report, 1970). Major services such as housing, education and personal social services (the latter as

\footnotetext{
${ }^{6}$ There are an additional 3 agencies within the Northern Ireland Office: Compensation Agency;
} 
an integrated provision with health) are delivered through quangos, many of which report to boards whose members are appointed by ministers or departmental civil servants. Planning is an Executive Agency in the Department of the Environment. The general trend toward quasi-government organisations is criticised by Weir (1995: 320) who argued 'in area after area of public life, elected government is being replaced by appointive government. Those who are elected count for ever less; those who are appointed count for ever more'. In an period of Direct Rule from Westminster the burgeoning number of quangos merely served to compound the democratic deficit in Northern Ireland. At March 2003 there were 2,061 public appointments to 99 public bodies (Central Appointments Unit, 2003). These range across the following bodies:

- Executive non-departmental public bodies (NDPBs) which carry out administrative, regulatory, executive or commercial functions (e.g. education and library boards; health trusts; health and social services boards; fire authority).

- Advisory NDPBs which provide independent, expert advice to Ministers and officials (e.g. Historic Building Council; Law Reform Advisory Committee; NI Water Council)

- Tribunals which have semi-judicial functions (e.g. Office of Industrial Tribunals; Planning Appeals Commission

- Other bodies (e.g. Northern Ireland Transport Holding Company; Rural Development Council; Registered Housing Associations)

- Boards of visitors to penal institutions. 


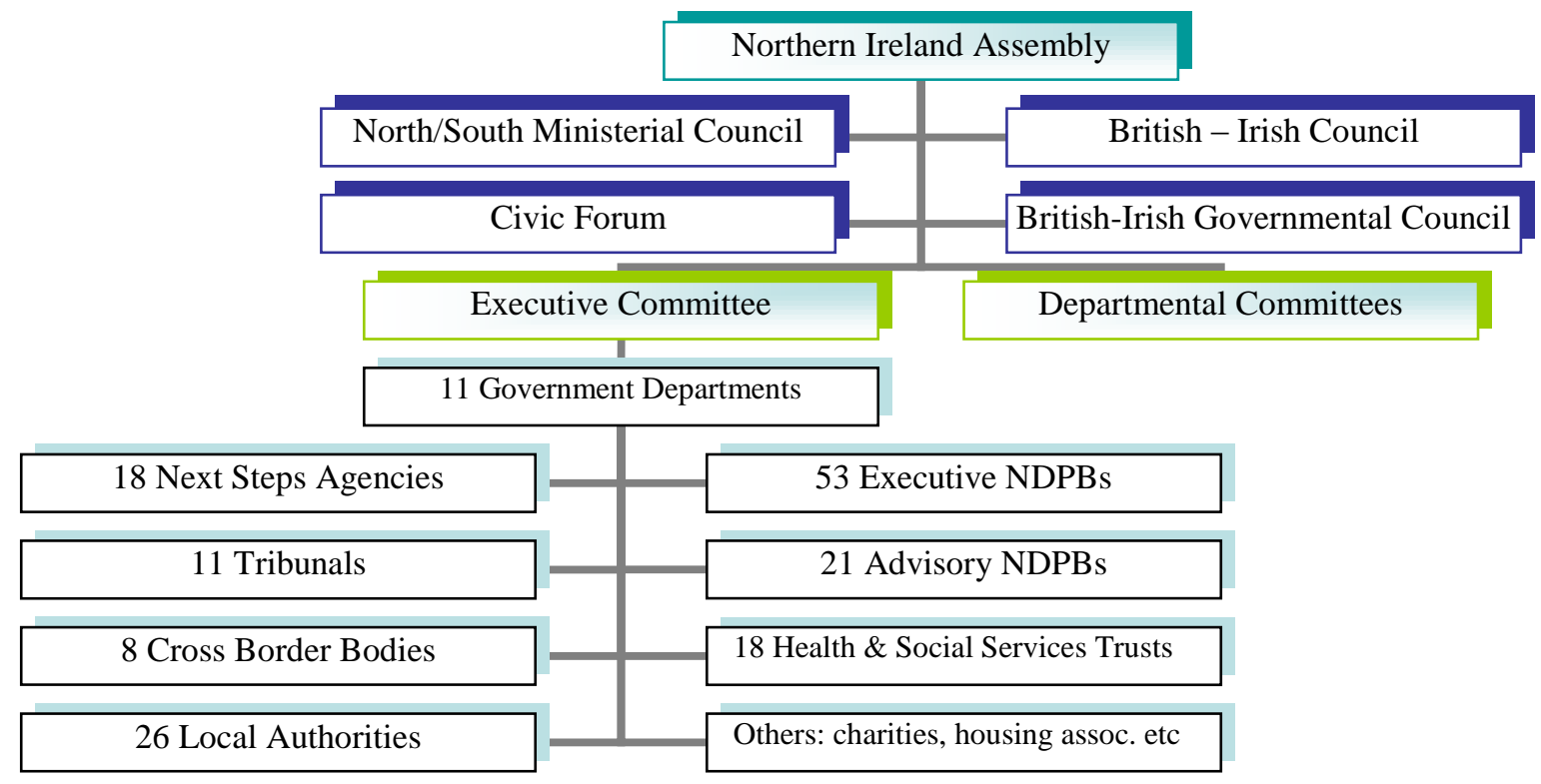

The system of appointment to these bodies has been the subject of review, and procedures now conform to 7 principles: ministerial responsibility; merit; independent scrutiny; equal opportunities; probity; openness and transparency; and proportionality. A Commissioner for Public Appointments (NI) conducts an annual audit to ensure compliance with these principles. This, however, does little to dispel public perceptions that a gravy train of quangocrats, comprising politically acceptable nominees, are responsible for a large amount of public expenditure in Northern Ireland.

Local government in Northern Ireland is the poor relation in the public sector and plays a relatively minor role in public service provision. This is a direct consequence of their abuse of powers during the Stormont era (1921-72). Typically, the role played by local authorities in the allocation of public housing and the imbalance in the senior ranks of public sector (local government and the civil service) gave rise inter alia to charges of deliberate bias against Catholics. Darby's (1976: 78) conclusion on the period that there was 'a consistent and irrefutable pattern of deliberate discrimination against Catholics' is supported by Whyte who argued that 'the most serious charge against the Northern Ireland government is not that it was directly responsible for widespread discrimination, but that it allowed discrimination on such a scale over a substantial segment of Northern Ireland' (Whyte, 1983: 31). Local authorities were therefore stripped of their powers. Since 1973 the 26 single tier authorities are elected every 4 years by STV proportional representation and spend around $£ 340 \mathrm{~m}$ annually or $4.4 \%$ of the public budget (Department of the Environment, 2003). Local councils 
have three main roles: an executive role in which they provide certain regulatory services (e.g. building regulations, environmental health) and a limited range of functions such as street cleaning, refuse collection, cemeteries and crematoria, recreation and tourist amenities and economic development; a representative role where members are nominated to serve on area boards (e.g. education and library boards); and a consultative role where councils' views are sought on centrally provided services such as planning, roads, water and housing. Despite their limited range of powers, councils have been successful advocates in brokering the disjointed services of other public sector bodies for the benefit of their areas. Importantly, for successive periods of Direct Rule, local government remained the only democratic forum in Northern Ireland and led the way in promoting power-sharing between the main political parties before the principles of proportionality and cross community consent were embedded in the Belfast (Good Friday) Agreement and the workings of the Assembly.

In sum, the administrative arrangements for a small population are complex, hugely bureaucratic and confusing to the public. One observer recently described the infrastructure of the Northern Ireland state apparatus as 'bloated, unwieldly and not fit for purpose'. He argued 'it is more collectivist than Stalinist Russia, more corporatist than Mussolini's Italy and more quangoised than the Britain of two Harolds' (Smith, 2004: 67). An eloquent, if over-the-top, description containing, nonetheless, a modicum of truth. 


\section{The context for reform}

A number of contextual factors had an important bearing on the impetus for the Review of Public Administration. The most obvious change driver was devolution in Northern Ireland which followed the Belfast (Good Friday) Agreement 1998 and the establishment of an elected Assembly and Executive. When the powers of government were devolved on $2^{\text {nd }}$ December 1999 to local members of the legislative assembly (MLAs), one of their priorities was to reform and modernise public services, a policy consistent with the Westminster modernisation agenda. The Northern Ireland reform agenda has three main foci: investing in the infrastructure needed to deliver public services; improving public services; and a Review of Public Administration to look at who provides services, the way they are provided, and how effectively they meet the needs of the citizen (Northern Ireland Executive, 2002). The (then) First Minister noted in an Assembly debate:

The Review of Public Administration is one of the major tasks facing the Executive and will be central to the way in which we deliver, structure and organise our public services in the future. This is an opportunity of a generation to put in place a modern, accountable, effective system of public administration that can deliver a high quality set of public services to our citizens (Trimble, 2002: 371).

There was agreement amongst politicians that the plethora and complexity of public bodies inevitably resulted in Northern Ireland being over-administered, if not overgoverned, with 3 MEPs, 18 MPs, 108 MLAs and 582 councillors. Importantly however, the First Minister was reluctant to upset the administrative architecture so carefully negotiated to achieve a power-sharing Executive. Hence non-departmental public bodies, local government and 'Next Steps' Agencies are part of the Review but the 11 government departments have been ruled out. The official rather abstruse position is 'the Review is likely to have implications for the functions exercised by the Executive, but the institutions established by the Agreement and the division of functions between the 11 departments will not be part of the Review's remit' (OFMDFM: 2002). With this important omission, the terms of reference for the Review, launched in June 2002, are: 
To review the existing arrangements for accountability, administration and delivery of public services in Northern Ireland, and to bring forward options for reform which are consistent with the arrangements and principles of the Belfast Agreement, within an appropriate framework of political and financial accountability (Review of Public Administration, 2002).

The Review is being led by a multi-disciplinary team of officials in the Office of the Minister and Deputy First Minister, working with the advice of a team of independent experts. Whilst most politicians welcomed the Review, there were notable exceptions. Robert McCartney (UK Unionist, MLA) argued strongly against the exclusion of the 11 government departments criticising this as a means of shoring up the Northern Ireland Executive. 'Under the d'Hondt system, the four main parties that provide the 10 ministers have a vested interest in continuing as before.. there is no effective opposition, no joined-up government and no Cabinet responsibility. There are 10 independent warlordships' (McCartney, 2002). There were also criticisms of the fact that the Review was being led by civil servants in the Office of the First Minister and Deputy First Minister reporting to a subcommittee of the Executive. Characterising civil servants as 'budget maximising bureaucrats' (Dunleavy, 1991) in a rhetorical question, McCartney continued 'officials will have a vested interest in keeping their own administrative empires going - who has ever heard of a civil servant who has been anxious to reduce the number beneath him (sic) in the pyramid?' There is empirical support for this view expressed by Grindle (2001:31) who found in other reform studies that the organisation of service delivery was of little interest to users or citizens. Reform, he claimed, is generally an elite process 'it is not public demands, the legislature or interest groups that define reform initiatives but small groups located in the executive'.

The (Direct Rule) Minister now responsible for overseeing the Review has noted that 'improving services to the public lies at the heart of any new model of public administration' (Pearson, 2004a). There is an acknowledgement that the 'reform process is not an end in itself and is only of value if it results in measurably better services for the public that deliver real value for money' (OFMDFM, 2004: 89).

The Review Team has been charged with fulfilling the following 10 characteristics in making recommendations for change: 
1. Democratic accountability: to ensure the democratic oversight by elected representatives of services provided within their area of responsibility and holding to account those delivering other services not directly within their remit.

2. Community responsiveness: to make services responsive to local needs and variations in those needs.

3. Cross-community concerns: to protect the concerns of communities which are in a minority in different parts of Northern Ireland, in terms of delivery and accountability of public services and ensuring proper protection of their interests.

4. Equality and human rights, including equity of access: to provide and deliver services fairly throughout Northern Ieland so that any new arrangements from the Review comply with equality and human rights legislation.

5. Subsidiarity: to consider which services are best developed, overseen and delivered at local level, sub-regional and regional levels and the co-ordination of policy making and service delivery across these levels.

6. Quality of Service: to ensure that services are delivered as efficiently and effectively as possible to certain quality standards.

7. Co-ordination and integration of services: to examine the potential for cooperation between different types of services to deliver cross-cutting policies.

8. Scope of the public sector: to assess the appropriateness of services being provided by the public sector and the role of the private and community/voluntary sector in contributing to better public services.

9. Efficiency and effectiveness: to consider the best use of resources so that any reorganisation creates the most effective and efficient services to the public, avoiding duplication, minimising managerial and bureaucratic expenditure and maximising spending on front-line services.

10. Innovation and business organisation: to be forward-looking by examining the needs of people in 5-10 years time through opportunities arising from new technology and better ways of delivering services.

(Adapted from Review of Public Administration, 2002).

The original timescale for the Review (launched in June 2002) was an interim report, following consultation, to the Northern Ireland Executive by Spring 2003 and final recommendations on a preferred model by the end of 2003. All of this assumed the continuance of devolved government with the Northern Ireland Executive taking ownership of this key policy development. Devolution, however, has been 
intermittent and faltering ${ }^{7}$ plagued by a series of incidents giving rise to the lack of trust between the political parties and loss of confidence in the outworkings of the Belfast (Good Friday) Agreement amongst unionists. With the Assembly now in suspension for fourth time since October 2002, the Secretary of State, whilst acknowledging that the key decisions should be taken by the devolved government, has continued to progress the work of the Review consulting with the main political parties as necessary. The government intends to produce a 'firm proposals document' for consultation in Autumn 2004 with a view to legislating on changes in Spring 2005 and an implementation date in time for the local government elections of 2009.

\section{Progress Report}

What have been the keys outputs from the Review thus far? The Review Team has been industrious. It has engaged in widespread consultation and research broadly categorised as: public attitude surveys on their experiences of government services; study visits to other jurisdictions (Europe, North America, Australia and New Zealand) which examined how public services were structured and delivered; qualitative (focus group) engagement with key stakeholders (general public; providers and users of public services; and public sector staff); organisational mapping of the public sector; and briefing papers on key issues in public administration. The findings from the above work informed a consultation paper launched in October 2003 which set out five possible models for consideration in rethinking the structural architecture of public services.

\footnotetext{
${ }^{7}$ There have been 4 periods of devolution in Northern Ireland since the Belfast (Good Friday) Agreement: $2^{\text {nd }}$ December $1999-11^{\text {th }}$ February 2000;30 $30^{\text {th }}$ May $2000-10^{\text {th }}$ August 2001; $12^{\text {th }}$ August $2001-21^{\text {st }}$ September 2001; and 23 ${ }^{\text {rd }}$ September $2001-14^{\text {th }}$ October 2002.
} 
1. Status Quo: This model envisages no change to the overall structure of public administration.

2. Centralised: Under this model all major services would be delivered directly by government departments.

3. Regional and Sub-Regional Public Bodies: A range of public bodies, operating either regionally or sub-regionally, would deliver public services.

4. Reformed Status Quo with enhanced Local Government: While keeping the main features of the current system, local government would be given new responsibilities.

5. Strong Local Government: Major public services would be the responsibility of a smaller number of new councils.

(Review of Public Administration in Northern Ireland, 2003: 25-29).

The consultation ended in February 2004 and attracted 170 written responses. The general points emerging from the responses were:

- There is unanimous support for the need for change and a demand for early action.

- 'Quality of service' is seen as more important than the means by which the service is delivered.

- There is a widespread consensus on the need for fewer public bodies, with more collaboration and less fragmentation.

- There is a preference for models 4 and 5 above with fewer quangos and a smaller number of larger councils having more powers.

- Co-terminosity of administrative boundaries is seen as essential to facilitate effective collaboration.

- There is a recognition that some services are best delivered centrally but there is scope for more local delivery than at present.

- The Assembly, Executive and Departments should be responsible for policy and strategic development, as well as monitoring standards, but not for the delivery of services.

- While some aspects of health are best delivered regionally, most services should be delivered by sub-regional organisations each serving populations of approximately 250,000 . 
- There is a need for fair and robust governance arrangements to ensure transparent decision-making and protection of minority interests.

(Northern Ireland Executive, 2004)

In light of the consultation findings the (Direct Rule) Minister made his preference known for the shape of the final model, due to go out for consultation in Autumn 2004 , by suggesting a two-tier system of regional and sub-regional bodies. At the regional level the Assembly and government departments will be responsible for policy development, strategic planning, setting standards and monitoring performance. Regional authorities and 'Next Steps' Agencies will deliver those services of province-wide import. At the sub-regional level the emphasis will be on service delivery through larger local authorities and sub-regional bodies with councilled community planning and civic leadership (see figure 3 ).

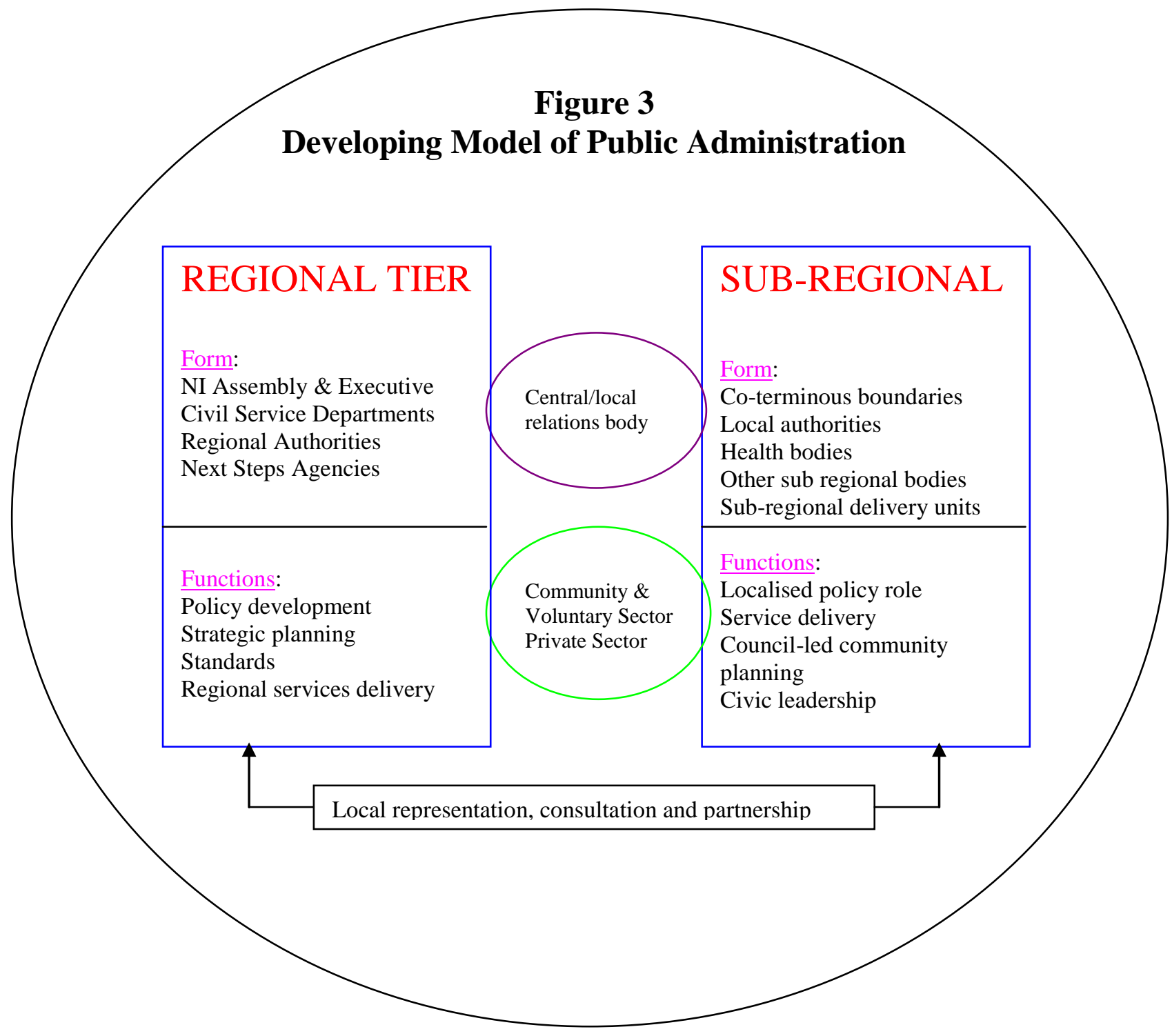


The Minister commented 'it is clearly evident that people want the Review to move ahead without delay, that improving the quality of public services should be the prime consideration for reform, and that there are too many public bodies at present and a lack of effective co-ordination and collaboration between service providers' (Pearson, 2004b). He summarised the likely detail of his final model thus:

- a significant reduction in the number of public bodies, including health service bodies;

- the reduction in the number of councils from 26 to between five and eight more powerful councils which could have responsibilities for an increased range of functions such as regeneration, environmental services, some planning functions and local roads, delivered within administrative boundaries which are aligned with other service providers;

- arrangements at local level to safeguard the maintenance of local identity and community input to decision-making; and

- robust governance arrangements to ensure transparent decision-making, fairness and the protection of minority rights.

\section{Evaluating the proposed reforms}

Toonen (2003) argues that administrative reform as a process is best conceived of as somewhere on a continuum between planned change on the one hand and emerging incremental strategy on the other. Whilst reform is often presented as the outcome of a planned approach, in practice however the process of consultation and negotiation among the institutional and administrative interests turns grand stated ambitions into modest changes. He suggests:

Reform is best conceived of as a long-term, less rationally designed, piecemeal and cyclical process. A process that is full of inconsistencies, and self-induced consequences, but also with expected serendipities, which, in the long run, may actually generate some decent results, next to the misses inherent to any experimental and learning processes (Toonen, 2003: 473). 
Importantly he goes on to argue that whilst economic pressures in the 1970s and 1980s forced governments in the Western world into a series of institutional and budgetary reforms we should not disregard the importance of politics, ideology and leadership. 'Politics matters in administrative reform, particularly in terms of politically framing the problem, timing the initiatives and setting the reform agenda' (Toonen, 2003:474). Yet, none of the characteristics for reforms make reference to political influences on the outcomes of the Review. Despite the absence of devolution, local political parties must be satisfied with (or at least acquiesce in) the outcomes of the Review, hence the Minister's desire for regular briefings. Thus far, given the Minister's preference for fewer councils, some political parties are promoting the idea of 18 local authorities based on Westminster boundaries. This, of course, makes the political calculus simple and the number of unionist/nationalist controlled councils relatively easy to predict. The Minister is also anticipating the restoration of devolution, at which point local MLAs must assume ownership of his proposals and implement the necessary changes.

According to Frost (2002), reforming the organisational structure of the public service is a key strategy in improving efficiency within government. Restructuring seeks to address three concerns, that: policy makers have become distanced from the public; the public service has become inflexible; and the public service has become inefficient. He argues that a key challenge is that boundaries are no longer clear with the increasing varieties of operating or executive agencies. As a consequence the traditional lines between the public service and the broader public sector are now harder to trace. A second and related challenge, he suggests, concerns the attraction of the one-off 'big-fix' solution to public service shortcomings:

Changing organisational structures can, at some considerable human and financial cost, address structural problems. If the problems are more directly related to managerial practices and support systems, or to weak or uncertain ethical frameworks, structural solutions are an expensive method for answering the wrong question (Frost, 2002: 90).

This highlights one systemic flaw in the Northern Ireland Review of Public Administration - its emphasis on structural reorganisation. The review is being hailed 
as a means of improving the quality of public services. But it is doing so in the absence of a modernising agenda. Key policy initiatives in the rest of the United Kingdom such as Modernising Government (1999), Reforming our Public Services Principles into Practice (2002) and the most recent policy debate contained in The Future of Local Government: Developing a 10 year Vision (2004) have all but bypassed Northern Ireland. This is exemplified by the public service agreement for the Public Service Reform Unit in Northern Ireland whose key target is 'to ensure through the Freedom of Information Act, rights of access to information by January 2005' (OFMDFM, 2004: 137). Hardly core to improving public services!

Parallel concerns about institutional restructuring have been expressed in New Zealand, regarded as an international model of public services reform. Evidence of efficiency gains have been crowded out by unease over restructuring. Shaw (2000: 275) argued that organisational change 'saps morale and loyalty, drains institutional wisdom and experience, and deflects the attention of public servants away from their primary responsibilities to citizens'. In short, reorganisation becomes an end in itself for public servants pre-occupied with their vested career interests.

The literature on public service reform is dominated by the extent to which countries have embraced the elements of new public management - budgetary reforms, marketisation and privatisation, efficiency and effectiveness, decentralisation and a customer orientation (Pollitt and Bouckaert, 2000; McLaughlin, Osborne and Ferlie, 2002; Lynn, 2003). In Northern Ireland the reform agenda appears entirely institutional in nature. Such managerial reform as has taken place is through a process of 'read-across' from the Great Britain rather than a dedicated public service reform agenda. According to Batley (2004) reform entails more than restructuring institutions. It is not, he claims 'just a technical matter of finding the best design solution and applying it...nor is reform only a narrowly political process of confronting specific interests.. it is a more complex reality where political and administrative arrangements embody values, behaviour and structures of power' (Batley, 2004: 36).

By way of a formative evaluation of the proposed changes, a number of specific observations can be made. First, concern has been expressed that the Review has 
become a review of local government rather than public administration in its widest sense. This perception has been fuelled by the Minister's early (some have suggested premature) declaration that the number of councils will reduce from 26 to 5 - 8 local authorities with greater powers. His early pronouncements also contravene the principle that 'form' should follow 'functions' - agree what functions each tier of government should deliver and develop a structural model which best fits the functional split. The Minister has made imprecise references to functions which larger councils 'could have responsibility for' but, in advance of the final consultation round, has already predetermined (within narrow limits) the structural configuration of local government in the future.

Second, the focus on local government as the most visible manifestation of public service deliverers draws attention away from other significant public administration players. The 'Next Steps' Agencies for example, employing $48 \%$ of the civil service, receive no mention in any future reform plans. It is conspicuous that none of the 18 agencies even responded to the first consultation document although they are clearly within the remit of the Review, adding credence to the view that this is a review of local government. This is either a puzzling oversight on their behalf or part of an accepted wisdom that any Review will not meddle with the machinery of central government. If, for example, the functions of the 4 key agencies within the Department of the Environment ${ }^{8}$ were to be relocated, its raison d'être would be in serious doubt. The same could be said of the Department for Regional Development where the removal of the functions of its 2 major agencies ${ }^{9}$ would leave the department as a hollow shell.

Third, the need for administrative reform in Northern Ireland has a focal point around the issue of quangos or non-departmental public bodies. Pre-devolution, quangos had been an attractive option for Direct Rule Ministers. The presence of a powerless local government forum, the need for government to distance itself from functions such as housing which had been tarnished by sectarian malpractice, and the usefulness of strengthening participative democracy through nominees on quangos in a Province

\footnotetext{
${ }^{8}$ The 4 agencies in the Department of the Environment are: Planning Service; Driver and Vehicle Licensing Agency; Environment and Heritage Service; and, Driver and Vehicle Testing Agency.
} 
with a democractic deficit (Direct Rule from Westminster) created circumstances where quangos flourished. Post-devolution, representative democracy was in the ascendancy and MLAs flexed their combined political muscle to dismantle quasigovernment seeing the Review of Public Administration as the means of so doing. Such expectations need to be dampened from the experience elsewhere. In Wales, for example, the Welsh Development Agency, Education and Training Body (ELWa), and the Wales Tourist Board will be abolished from April 2006 and their staff and functions absorbed into the Assembly Government civil service. These three bodies represent 'some two-thirds of quangoland' according to First Minister Rhodri Morgan (Osmond, 2004: 2). In Scotland, where a similar exercise took place radical intentions to reform quangos did not result in the expected cull. As one observer of the Scottish case noted 'for those hoping for an end to quangos following devolution there is disappointment. Though bonfires were promised, as institutions NDPBs have proven to be remarkably flame-resistant' (Orr, 2003: 167). What resulted was described by the Scottish Executive as a 'timely tidying-up, modernising exercise' (Scottish Executive, 2001:2, cited by Orr). These may be prophetic words for Northern Ireland's reformers.

Fourth, there are concerns that the move to reduce the number of local authorities to 5 - 8 will significantly impact on the sense of locality upon which the current 26 principal towns/cities and associated councils are predicated. The sense of place is strong in Northern Ireland and local councillors, despite their lack of responsibility for major public services, have been the first port of call for constituents in need of help and advice. Even with the devolved Assembly and Executive (since 1999), recent evidence shows that councillors are contacted much more regularly than MLAs or MPs (O'Brien, 2003). Although the Minister has flagged the issue of local identity as an issue for the final consultation paper in the Review, there appears to be little appetite amongst existing local authorities for a lower symbolic tier of community councils whose primary role would be advocacy. Equally, the Review Team is against proposing a two-tier system of local government when their primary purpose is to cut an over-administered system of public administration.

\footnotetext{
${ }^{9}$ The 2 key agencies in the Department for Regional Development are the Water Service and the Roads Service.
} 
Fifth, any proposals for a strong local government also call into question its role vis-àvis the Assembly. The proposed central/local split (see figure 3 above) envisages the Assembly responsible for policy development and strategic planning, and councils as sub-regional services deliverers. Importantly, councils are likely to play a key role in other functions which might not fall within their remit such as health, education and housing - through new powers of 'well-being' and the democratisation of bodies charged with the delivery of these functions. This places local government in a powerful functional role, one whose significance may be more obvious to electors than the Northern Ireland Assembly. Currently almost two-thirds of members of the Assembly are also local councillors (69 councillors within the108 MLAs) raising questions about whether there is a need for this number of MLAs to represent $1.7 \mathrm{~m}$ population. By way of comparison there are 129 Members of the Scottish Parliament (population 5.05m) and 60 Welsh Assembly Members (population $2.92 \mathrm{~m})^{10}$. Scotland and Wales also have more traditional local government systems.

On what basis will the outcomes of the Review be judged? Clearly, the final model must meet its terms of reference which emphasise that the reforms should be 'consistent with the arrangements and principles of the Belfast (Good Friday) Agreement and within an appropriate framework of political and financial accountability'. These terms are broadly cast and sufficiently nebulous (what does 'appropriate framework' mean?) to claim most outcomes fulfil the brief. What will be more difficult to realize however are the 10 characteristics of the Review. There is no ranking associated with these characteristics and hence the assumption must be that they are all equally important. Moreover, there is no acceptance that some may incongruous. For example, Review proposals which promote cross-community concerns must acknowledge that Northern Ireland is an increasingly polarised society. Typically in the public housing sector over $70 \%$ of housing estates are more than $90 \%$ Protestant or Catholic (OFMDFM, 2003b). The consequences of this acute segregation are the financial costs of duplicating public services for each of the communities due to low inter-community mobility and the additional costs of addressing sectarianism. As one research report noted:

\footnotetext{
${ }^{10}$ In Northern Ireland there is one MLA per 15,740 population; in Scotland one MSP per 39,150 people; and in Wales Assembly Member per 48,700 population.
} 
The divided community within Northern Ireland creates an environment where provision of public services is more expensive and additional community relations services are required. These additional costs span a large number of departments and range from programmes introduced to break down social barriers between communities to additional expenditure required to attract visitors to the region (Harbison, 2002: Appendix 6:58).

Hence to meet the Review's characteristic of protecting minority communities seems incompatible with their goals of 'efficiency and effectiveness' where they explicitly refer to 'avoiding duplication of services'. Other potential anomalies include the impact of attempts to operationalise the principle of subsidiarity on the efficiency of public service provision, particularly economies of scale. Despite their goal of coordinated and integrated services there may well be problems in joined-up provision between the regional services (through the Assembly), sub-regional services (through councils), other sub-regional services (through health, housing bodies) and a rump of non-departmental public bodies which may remained untouched by the reforms (such as the Northern Ireland Housing Executive). 


\section{Improved public services?}

Ultimately the Review of Public Administration must demonstrate that 'it results in measurably better services for the public that deliver real value for money' (OFMDFM, 2004: 89). This is a useful touchstone for the Review but a tall order, not least because of definitional issues as to what constitutes 'better services' which deliver 'real value for money'. We can examine current public attitudes to service provision from baseline information, drawing on two sets of survey data - the Northern Ireland Omnibus Survey $(2002: \mathrm{n}=1,203)$ and the Northern Ireland Life and Times Survey $(2003: \mathrm{n}=1,800)^{11}$. The data show that $45 \%$ of respondents were satisfied or very satisfied with public services in Northern Ireland; 20\% stated they were either dissatisfied or very dissatisfied; and $34 \%$ reported they were neither

\section{Satisfaction with Public Services}

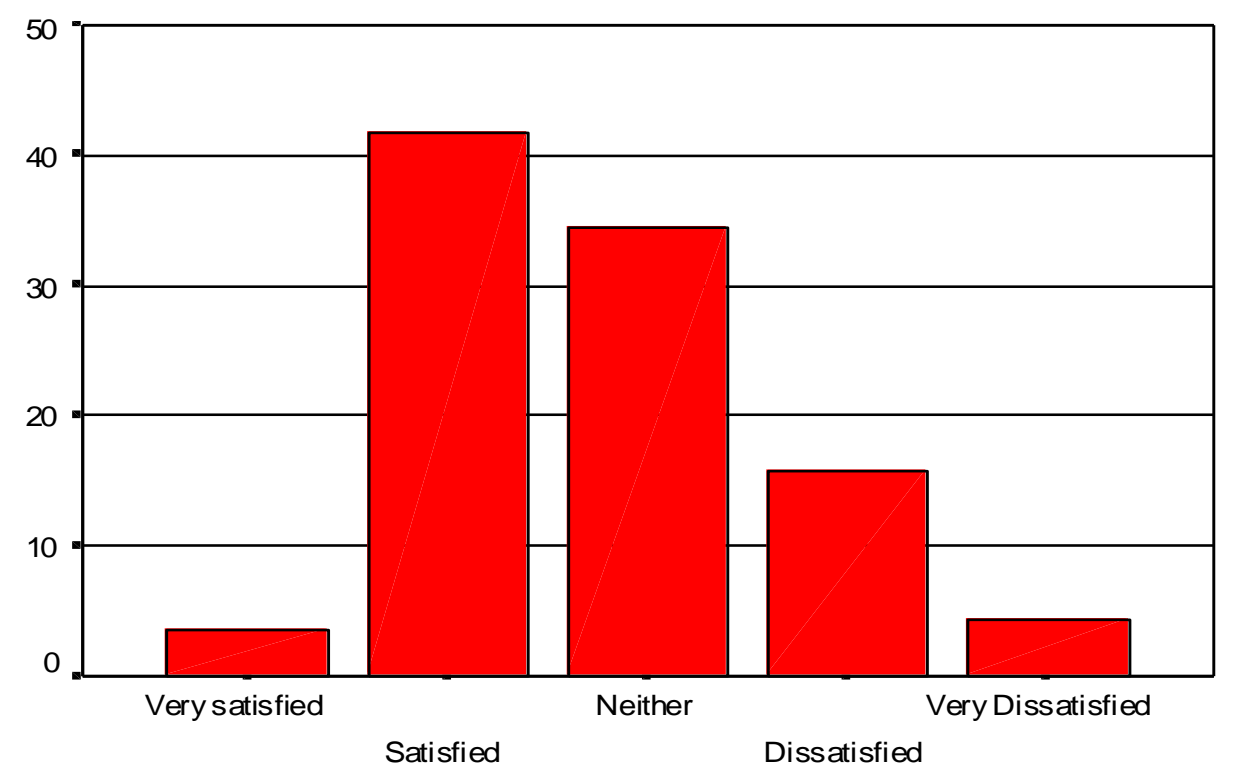

Figure 4

satisfied nor dissatisfied (see figure 4).

Survey respondents were further asked whether education, health and the economy had 'got better', 'worse', or 'stayed the same' under the last Northern Ireland Assembly (23 $3^{\text {rd }}$ September 2001 to $14^{\text {th }}$ October 2002), and since the suspension of the Assembly (Direct Rule). The results are set out in table $1^{12}$.

\footnotetext{
${ }^{11}$ The Northern Ireland Omnibus Survey (2002) questions were commissioned by the Review of Public Administration. Data were gathered using probability sampling from 1,203 respondents face-to-face across Northern Ireland. The Northern Ireland Life and Times Survey (2003) involved 1,800 face-toface interviews from randomly selected respondents throughout Northern Ireland.

${ }^{12}$ Figures exclude 'don't know' and 'other answer'.
} 
Table 1: Public Services - devolution and direct rule

\begin{tabular}{|l|l|l|l|l|l|l|}
\hline & \multicolumn{2}{|c|}{ Education \% } & \multicolumn{2}{c|}{ Health \% } & \multicolumn{2}{c|}{ Economy \% } \\
\hline & $\begin{array}{l}\text { Devolved } \\
\text { Government }\end{array}$ & $\begin{array}{l}\text { Direct } \\
\text { Rule }\end{array}$ & $\begin{array}{l}\text { Devolved } \\
\text { Government }\end{array}$ & $\begin{array}{l}\text { Direct } \\
\text { Rule }\end{array}$ & $\begin{array}{l}\text { Devolved } \\
\text { Government }\end{array}$ & $\begin{array}{l}\text { Direct } \\
\text { Rule }\end{array}$ \\
\hline Better & 26.4 & 7.0 & 16.3 & 6.3 & 24.4 & 5.8 \\
\hline Worse & 16.3 & 13.2 & 34.9 & 24.8 & 18.7 & 19.3 \\
\hline Same & 57.4 & 79.8 & 48.7 & 68.9 & 57.0 & 74.9 \\
\hline
\end{tabular}

Considering one of these services (the economy) in more detail demonstrates a significant difference in performance under devolved government and direct rule arrangements (see figure 5). The results can be compared with service improvements in other devolved regions of the United Kingdom which have been relatively low. For example, in Scotland and Wales, $23 \%$ and $24 \%$ of survey respondents felt standards had improved in the National Health Service; $27 \%$ and $30 \%$ in education; $30 \%$ and $31 \%$ in the general standard of living, respectively (Jeffery, 2004).

\section{Devolution \& Direct Rule} Figure 5

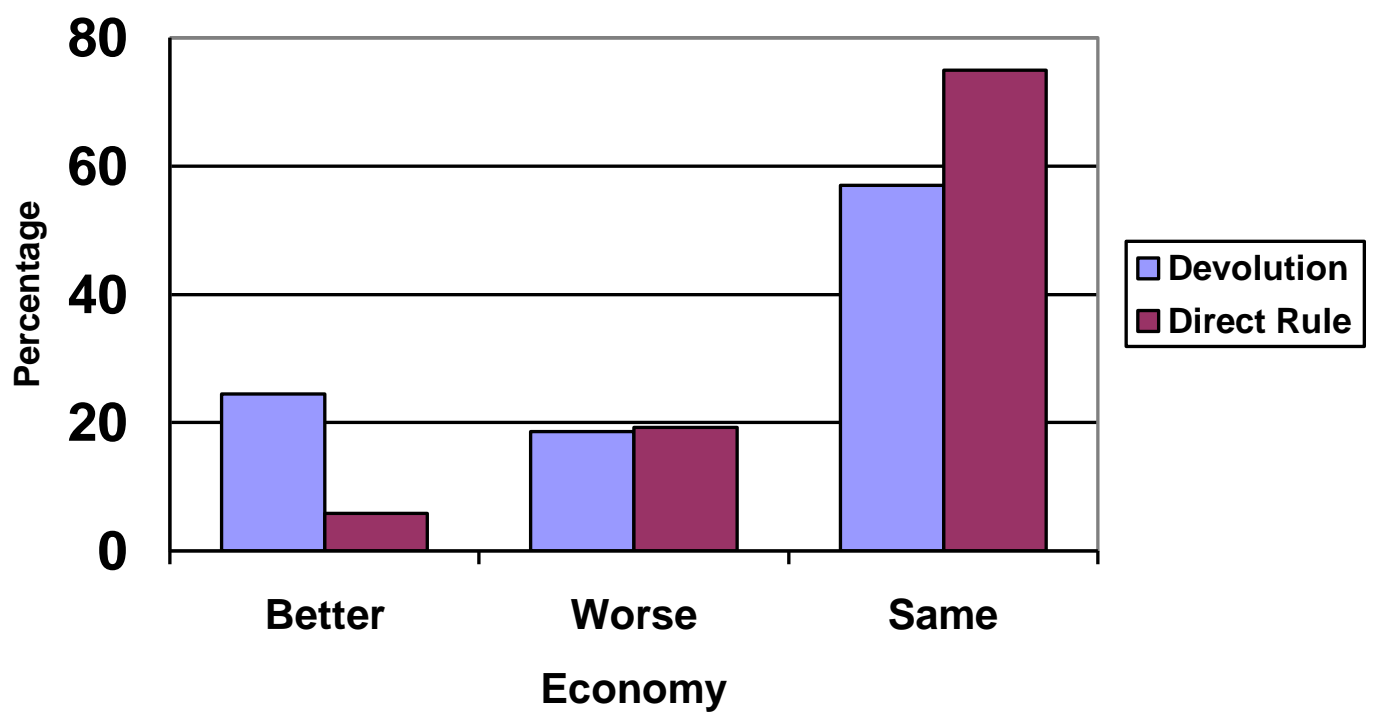


Using Wilcoxon matched-pairs signed-ranks test we compared the two types of administration (Direct Rule and devolution) ${ }^{13}$. The results are shown in tables $2 \& 3$ and illustrate a significant improvement in the economy and education under devolved government but no significant difference in health services (see table 3 for significance levels).

Table 2: Direct Rule and Devolution Comparing Education, Health and the Economy

\begin{tabular}{|c|c|c|c|c|}
\hline & & $\mathrm{N}$ & $\begin{array}{l}\text { Mean } \\
\text { Rank }\end{array}$ & Sum of Ranks \\
\hline \multirow{3}{*}{$\begin{array}{l}\text { Education under Direct } \\
\text { Rule }\end{array}$} & \multirow{4}{*}{$\begin{array}{l}\text { Negative ranks } \\
\text { Positive ranks } \\
\text { Ties } \\
\text { Total }\end{array}$} & \multirow{4}{*}{$\begin{array}{l}386^{\mathrm{a}} \\
194^{\mathrm{b}} \\
893^{\mathrm{c}} \\
1473\end{array}$} & 294.34 & 113616.00 \\
\hline & & & 282.86 & 54874.00 \\
\hline & & & & \\
\hline $\begin{array}{l}\text { Education under } \\
\text { devolution }\end{array}$ & & & & \\
\hline \multirow{4}{*}{$\begin{array}{l}\text { Health under Direct Rule } \\
\text { Health under devolution }\end{array}$} & \multirow{4}{*}{$\begin{array}{l}\text { Negative ranks } \\
\text { Positive ranks } \\
\text { Ties } \\
\text { Total }\end{array}$} & \multirow{4}{*}{$\begin{array}{r}283^{\mathrm{d}} \\
305^{\mathrm{e}} \\
986^{\mathrm{f}} \\
1574\end{array}$} & 304.41 & 86148.00 \\
\hline & & & 285.30 & 87018.00 \\
\hline & & & & \\
\hline & & & & \\
\hline \multirow{3}{*}{$\begin{array}{l}\text { The economy under } \\
\text { Direct Rule }\end{array}$} & \multirow{4}{*}{$\begin{array}{l}\text { Negative ranks } \\
\text { Positive ranks } \\
\text { Ties } \\
\text { Total }\end{array}$} & \multirow{4}{*}{$\begin{array}{r}370^{\mathrm{g}} \\
162^{\mathrm{h}} \\
998^{\mathrm{i}} \\
1530\end{array}$} & 279.24 & 103317.00 \\
\hline & & & 237.41 & 38461.00 \\
\hline & & & & \\
\hline $\begin{array}{l}\text { The economy under } \\
\text { devolution }\end{array}$ & & & & \\
\hline
\end{tabular}

a. Education under direct rule < education under devolution

b. Education under direct rule > education under devolution

c. Education under devolution $=$ education under direct rule

d. Health under direct rule $<$ health under devolution

e. Health under direct rule $>$ health under devolution

f. Health under devolution $=$ health under direct rule

g. The economy under direct rule $<$ the economy under devolution

h. The economy under direct rule $>$ the economy under devolution

i. The economy under devolution $=$ the economy under direct rule

\footnotetext{
${ }^{13}$ This test takes account of the size of the differences between two sets of related scores (people's opinions on education, health and the economy under devolution and direct rule) by ranking and then summing those with the same sign. If there are no differences between the two samples, then the number of positive signs should be similar to that of the negative ones (see for example table 2: negative and positive ranks for health).
} 
Table 3: Differences across Education, Health and the Economy Test Statistics ${ }^{\mathrm{c}}$

\begin{tabular}{|l|l|l|l|}
\hline & $\begin{array}{l}\text { Education under } \\
\text { direct rule - } \\
\text { education under } \\
\text { devolution }\end{array}$ & $\begin{array}{l}\text { Health under direct } \\
\text { rule - } \\
\text { health under } \\
\text { devolution }\end{array}$ & $\begin{array}{l}\text { The economy } \\
\text { under direct rule - } \\
\text { the economy under } \\
\text { devolution }\end{array}$ \\
\hline $\mathrm{Z}$ & $-7.860^{\mathrm{a}}$ & $-.114^{\mathrm{b}}$ & $-9.764^{\mathrm{a}}$ \\
\hline $\begin{array}{l}\text { Asymp. Sig. (2- } \\
\text { tailed) }\end{array}$ & .000 & .910 & .000 \\
\hline
\end{tabular}

a. Based on positive ranks

b. Based on negative ranks

c. Wilcoxon signed ranks tests

What is surprising about the results is that the public's experiences of these services might suggest a rather different picture. Far from devolved government being a model of service excellence it was dogged by controversy. In health, for example, a protracted and unresolved debate over the rationalisation of acute hospitals in Northern Ireland was passed to Direct Rule Minister, Des Browne, who took the decision that quality of health care must take precedence over access and reduced the number of acute hospitals from 15 to 9 (with the addition of a new acute hospital in Enniskillen). Minister Bairbre de Brún had procrastinated over the decision, not least because the site for a new facility involved two Sinn Féin MPs battling it out for its location in each of their constituencies. Similarly, a decision on the site for a new centralised maternity unit in Belfast had to be taken by Direct Rule Minister, Angela Smith, as political controversy raged over its location. Bairbre de Brún's preferred venue at the Royal Victoria Hospital (in her West Belfast constituency) was selected, much to the chagrin of unionists. The devolved Sinn Féin minister also faced huge pressure over increased waiting lists. During her tenure Northern Ireland acquired the unenviable reputation of having the longest waiting list $(60,000)$ per capita in Europe, now reduced during Direct Rule (at March 2004) to 50,000 (Department of Health, Social Services and Public Safety, 2004).

In education, Sinn Féin Minister Martin McGuinness, following a review of the education selection system regulated by transfer tests in the last year of primary schooling (the so-called '11-plus'), unilaterally announced its abolition as one of the final acts of the devolved administration in October 2002. Direct Rule Minister Jane 
Kennedy was left to pick up the pieces of the proposed new system based on 'informed parental choice' through 'pupil profiles', and although the timescale for abolition has slipped considerable, the intention is still to end the current system of academic selection. Mr McGuinness also stopped the publication of school league tables under his tenure. In higher education the SDLP Minister, Sean Farren, pushed through the introduction of student fees against the advice of his statutory committee which advocated the Scottish model of abolishing up-front fees, introducing bursaries and establishing an income-contingent graduate endowment (Osborne, 2002).

The fact that the public records a significant improvement (or no significant difference) in key public services under devolved government in the face of these (selective) issues might suggest an association between service provision and constitutional arrangements. Since support for devolution (and its sine qua non, the Belfast (Good Friday) Agreement) is now ebbing away within the unionist population, accelerated by the IRA's intransigence on decommissioning, their attitudes to public services may well be conditioned by their increasing dissatisfaction with the outworkings of the Agreement. In short, it might be argued that how people perceive public services is contingent on their views on the constitutional arrangements (Direct Rule/devolved government) which, in turn, are linked to the Belfast (Good Friday) Agreement rather than the performance of delivery agents (central government departments/agencies, local government and non-departmental public bodies).

We examine this association between the following variables ${ }^{14}$ using logit analysis. Logit analysis is a regression style causal analysis and we test whether people's opinions on education, health and the economy are affected by their religion, attitude to the Northern Ireland Assembly, and support for the Belfast (Good Friday) Agreement.

\footnotetext{
${ }^{14}$ All the variables in the analysis were recoded to exclude categories such as 'don't know', 'other', 'not registered to vote' and 'refused'.
} 
Dependent variable:

- Education (deveduc) - respondent's opinion on whether education has 'got better', 'worse' or 'stayed the same' under the Northern Ireland Assembly.

Factors:

- Northern Ireland Assembly (niabol) - respondent's opinion on whether he/she would be 'pleased', 'sorry' or 'wouldn't mind either way' if the Northern Ireland Assembly were to be abolished and Northern Ireland returned to Direct Rule.

- Support for the Belfast (Good Friday) Agreement (votegfa) - how respondent's would vote on the Good Friday Agreement if it were held today: 'yes', 'no' or 'wouldn't vote'.

- Religion of respondent (religcat) - respondent's religion categorised as 'Catholic', 'Protestant' or 'no religion'.

We repeat this analysis using health and the economy as the dependent variables ${ }^{15}$.

Results:

Model 1 (Education) has a chi-square likelihood ratio $\chi^{2}(16)=15.4, \mathrm{p}=.50$

Model 2 (Health) has a chi-square likelihood ratio $\chi^{2}(16)=14.5, \mathrm{p}=.56$

Model 3 (the Economy) has a chi-square likelihood ratio $\chi^{2}(16)=10.6, p=.83$

All 3 models produce a 'good fit' to the data. Model 3, for example, suggests there is at least an $83 \%$ chance that any difference between the cell frequencies predicted by the model and the actual observed cell frequencies could be due to chance only, well within the conventional 0.05 cut-off level for a significance test.

We can conclude from the analyses that people's attitudes to public services are affected by their community background (religion); support for the Belfast (Good Friday) Agreement; and their endorsement of devolution. Examining the observed and expected frequencies (and adjusted residuals) in each model suggests that Catholics are significantly more likely than Protestants to vote for the Belfast (Good Friday) Agreement today; would be sorry to see the abolition of the Northern Ireland Assembly and a return to Direct Rule; and believe public services have got better under devolution. It is perhaps worth noting that because the health and education portfolios were held by two Sinn Féin ministers this may have influenced Protestant

\footnotetext{
15 The model designs are as follows:

Model 1: (Education): Constant + deveduc + deveduc $*$ votegfa $*$ niabol + deveduc $*$ niabol $*$ religcat + deveduc $*$ votegfa $*$ religcat

Model 2: (Health): Constant + devheal + devheal $*$ votegfa $*$ niabol + devheal $*$ niabol $*$ religcat + devheal $*$ votegfa $*$ religcat

Model 3: (Economy): Constant + devecon + devecon $*$ votegfa $*$ niabol + devecon $*$ niabol $*$ religcat + devecon $*$ votegfa $*$ religcat
} 
respondents' views on whether these services improved under their stewardship. On the other hand, the Minister for Enterprise, Trade and Investment was Sir Reg Empey (UUP) - the model of best fit $(\underline{p}=.83)$.

\section{Conclusion}

The Review of Public Administration, due to report on its final model in autumn 2004, has been described as a 'means to an end'. The 'end' is improved quality of public services in Northern Ireland. Yet political influences on both the process (the Review) and the product (public services) predominate. In terms of process, the parameters of the Review which excluded government departments were politically conceived from the beginning. Local politicians weaned on a diet of 'power without responsibility' during 30 years of Direct Rule from Westminster stand back while a British minister proposes radical reforms to local government, their interest piqued only by the political calculus of any new configuration in electoral boundaries.

In terms of product, of the Review promises an improvement in public services. But crucially the link between service quality and electoral accountability is missing in Northern Ireland, eclipsed by constitutional politics. People in Northern Ireland vote along unionist/nationalist cleavages, regardless of service provision. Hence, whilst the ten rational characteristics established as the benchmark for the final reform model are laudable, they will count for little in the face of an agenda dictated by 'high' politics and judged accordingly by the public. The public's perceptions of service quality are a commentary on devolution, the peace process, the Belfast (Good Friday) Agreement, and perhaps even the political affiliation of the Minister. Ultimately it is not the Review of Public Administration which will deliver improved public services but a system of devolved government in which the public hold to account the Northern Ireland Assembly on their performance and delivery of core functions, driven by a modernising agenda the absence of which is conspicuous. 


\section{References}

Batley, R. (2004) 'The Politics of Service Delivery Reform' Development and Change Vol. 35 (1): 31-56.

Bloomfield, K. (1998) 'Central Government' in K. Bloomfield and C. Carter (eds.) People and Government: Questions for Northern Ireland. York: Joseph Rowntree Foundation.

Carmichael, P. and Osborne, R. (2003) 'The Northern Ireland Civil Service under Direct Rule and Devolution' International Review of Administrative Sciences, Vol. 69 (2): 205-217.

Central Appointments Unit (2003) Public Appointments Annual Report 2002/03. Belfast: Office of the First Minister and Deputy First Minister.

Darby, J. (1976) Conflict in Northern Ireland; the Development of a Polarised Community. Dublin: Gill and Macmillan.

Department of the Environment (2003) District Council Rate Statistics 2003/04. Belfast: Local Government Division.

Department of Health, Social Services and Public Safety (2004) Northern Ireland Waiting Lists. Belfast: DHSS\&PS Information Release, $3^{\text {rd }}$ June 2004.

Dunleavy, P. (1991) Bureaucracy, Democracy and Public Choice. Hemel Hempstead: Harvester Wheatsheaf.

Efficiency Unit (1988) Improving Management in Government: the Next Steps. London: HMSO.

Frost, P. (2002) 'Selecting the appropriate structure' pgs 89-92 in W. Cox (ed.) Commonwealth Public Administration Reform 2003. London TSO (The Stationery Office).

Grindle, M.S. (2001) Designing Reforms: Problems, Solution and Politics. Faculty Research Working Paper No. RWP01-020. Cambridge MA: Harvard University, John F. Kennedy School of Government.

Harbison, J. (2002) Review of Community Relations Policy. Belfast: OFMDFM Community Relations Unit.

Jeffery, C. (2004) Devolution - what difference has it made? 'Public Attitudes, Devolution and National Identity'. Birmingham: ESRC Devolution and Constitutional Change Programme.

Knox, C. (1999) 'Northern Ireland: At the Crossroads of Political and Administrative Reform' Governance, Vol.12 (3): 311-328. 
Lidington, D. (2004) Northern Ireland Grand Committee. Hansard, $8^{\text {th }}$ July Column 009.

Lynn, L.E. 'Public Management' pgs 14-24 in B. Guy Peters and J. Pierre (eds.) Handbook of Public Administration. London: Sage.

McCartney, R. (2002) 'Review of Public Administration' Hansard, $24^{\text {th }}$ June.

McLaughlin, K., Osborne, S. and Ferlie, E. (eds.) New Public Management: Current Trends and Future Prospects. London: Routledge.

Modernising Government (1999) Cabinet Office Cm 4310. London: The Stationery Office.

Northern Ireland Act (1998) - A Summary Guide. London: Northern Ireland Office.

Northern Ireland Executive (2002) Draft Programme for Government. Belfast: Office of the First Minister and Deputy First Minister.

Northern Ireland Executive (2004) Review of Public Administration Consultation, $11^{\text {th }}$ June 2004. Belfast: Review of Public Administration.

Northern Ireland Information Service (2002) 'Minister: waiting list efforts need to be re-doubled'. Department of Health, Social Services and Public Safety, $5^{\text {th }}$ December.

O'Brien, T. (2003) Northern Ireland Omnibus Survey: Research Bulletin 2. Belfast: Review of Public Administration.

Office of the First and Deputy First Minister (2002) 'Preparations for the Review of Public Administration'. News Release $12^{\text {th }}$ February.

Office of the First and Deputy First Minister (2003a) Review of Public Administration Organisational Maps http://www.rpani.gov.uk/public_sector_maps.htm

Office of the First and Deputy First Minister (2003b) A Shared Future: A Consultation Paper on Improving Relations in Northern Ireland. Belfast: OFMDFM.

Office of the First Minister and Deputy First Minister (2004) Northern Ireland Priorities and Budget 2004-06. Belfast: Department of Finance and Personnel.

Orr, K. (2003) 'Scotland's quangos since devolution', Local Goverance Vol. 29 (3): 157-168.

Osborne, R. (2002) 'Making a Difference? The role of statutory committees in the Northern Ireland Assembly', Public Administration Vol. 80 (2): 283-299.

Osmond, J. (2004) 'Wales: Bonfire of the Quangos', Monitor. The Constitution Unit Bulletin - September Issue 28: 2-3. London: UCL. 
Pearson, I. (2004a) 'Improvements to Quality of Service key to Public Administration Reform' News Release $19^{\text {th }}$ July. Belfast: Office of the First Minster and Deputy First Minister.

Pearson, I. (2004b) 'Minister Moves Forward on Review of Public Administration' News Release $4^{\text {th }}$ May. Belfast: Office of the First Minster and Deputy First Minister.

Pollitt, C. and Bouckaert, G. (2000) Public Management Reform: A Comparative Analysis. Oxford: Oxford University Press.

Reforming our Public Service: Principles into Practice (2002). London: The Stationery Office. London: Office of Public Services Reform.

Review of Public Administration (2002) Terms of Reference and Parameters for the Review of Public Administration http://www.rpani.gov.uk/tor.htm

Review of Public Administration in Northern Ireland (2003). Belfast: Office of the First Minister and Deputy First Minister - RPA.

Rose, R. (1971) Governing without Consensus: An Irish Perspective. London: Faber.

Scottish Executive (2001) Public Bodies: Proposals for Change. Edinburgh: HMSO.

Shaw, R. (2000) 'Model without a Cause: public choice and bureaucratic reform in New Zealand', New Zealand Sociology Vol 15 (2): 251 - 283.

Smith Lord, of Clifton (2004) Northern Ireland Orders Grand Committee. Hansard $20^{\text {th }}$ July.

The Future of Local Government: Developing a 10 year Vision (2004). Office of Deputy Prime Minister.

Toonen, T.A.J. (2003) 'Administrative Reform: Analytics' pgs 467- 477 in B. Guy Peters and J. Pierre (eds.) Handbook of Public Administration. London: Sage

Trimble, D. (2002) 'Review of Public Administration' Hansard 371- 402, $25^{\text {th }}$ February. Belfast: Northern Ireland Assembly.

Whyte, J. (1983) 'How much discrimination was there under the unionist regime 1921-68? in T. Gallagher and J. O'Connell (eds.) Contemporary Irish Studies. Manchester: Manchester University Press.

Wilson, R. (2001) 'The Executive Committee' in R. Wilson (ed.) Agreeing to Disagree? A Guide to the Northern Ireland Assembly. Belfast: The Stationery Office. 